\title{
COMPARISON OF MICROTISSUE FORMING CAPACITY OF SH- SY5Y AND SK-N-AS CELL LINES
}

\author{
( SH-SY5Y VE SK-N-AS HÜCRE HATLARININ MIKRODOKU OLUŞTURMA \\ KAPASITELERININ KARŞILAŞTIRILMASI)
}

Aslı Aybike DOĞAN ${ }^{1}$, Şeyma TAŞDEMİR ${ }^{2}$, Aylin ŞENDEMİR ÜRKMEZ ${ }^{3}$

\begin{abstract}
Two-dimensional (2D) cell culture systems are important tools for basic in vitro research. However, they form a thin monolayer structure and poorly mimic the complex in vivo conditions in terms of biochemical signals, cell-cell and cell- extracellular matrix (ECM) interactions. In this study, we performed a comparative study on SH-SY5Y and SK-N-AS neuroblastoma cell lines in terms of their microtissue forming capacity. Both cell lines are commonly used to model neurodegenerative diseases in vitro. Cells were cultured using 3D Petri Dish ${ }^{\circledR}$ technique. The cells' microtissue forming capacity was observed morphologically and microtissues' size was analized. Results indicate that microtissue forming capacity of SH-SY5Ycell line was better than that of SK-N-AS cell line. SH-SY5Y microtissues can be used as an alternative, scaffold-free in vitro 3D model for neurodegenerative diseases and neuroblastoma research.
\end{abstract}

Keywords: Cell culture, Three-dimensional (3D) Cell culture, Microtissue, SH-SY5Y, SK-N-A

\section{$\ddot{O} Z$}

İki boyutlu (2B) hücre kültür sistemleri temel in vitro araştırmalar için önemli araçlar olmasina rağmen, biyokimyasal sinyal iletimi, hücre-hücre ve hücre-matris etkileşimleri gibi kompleks koşullar taklit ederken, in vivo modellere göre zaylf kalmaktadır. Bu çalışmada, in vitro nörodejeneratif hastalık model hücreleri olarak slklikla kullanilan SH-SY5Y ve SK-N-AS nöroblastom hücre hatlarının, 3D Petri Dish ${ }^{\circledR}$ tekniği ile mikrodoku oluşturma kapasiteleri karşılaştırılmış olup, mikrodokuların morfolojileri gözlemlenmiş ve boyut analizleri gerçekleştirilmiştir. Sonuç olarak, SHSY5Y mikrodokularının nörodejeneratif hastalıklar ve nöroblastoma çalışmaları için alternatif bir $3 B$ model olabileceği belirlenmişstir.

Anahtar Kelime: Hücre kültürü, Üç-boyutlu (3B) hücre kültürü, Mikrodoku, SH-SY5Y, SK-N-AS

\footnotetext{
${ }^{1}$ Ege University, Faculty of Engineering, Department of Bioengineering, 35100 Bornova/Izmir/Türkiye, asli.aybike.dogan@gmail.com

${ }^{2}$ Ege University, Faculty of Engineering, Department of Bioengineering, 35100 Bornova/Izmir/Türkiye, seymacogan@gmail.com

${ }^{3}$ Ege University, Faculty of Engineering, Department of Bioengineering, 35100 Bornova/Izmir/Türkiye, aylin.sendemir@ege.edu.tr (Corresponding Author)
} 


\section{INTRODUCTION}

When cells are cultivated on flat 2D culture systems, they form a thin non-physiological monolayer structure and poorly mimic the complex conditions like biochemical signals and nutrient gradients that are essential for tissue functioning, cell morphology, in vivo like cellcell and cell-extracellular matrix (ECM) interactions, and coordinated assembly of cells in living organism [1]. Three-dimensional (3D) cell culture systems eliminate all these drawbacks of 2D cell culture systems, provide a high surface area for growth and migration, which can be tuned to support other cell behaviors, such as morphology, viability, proliferation, response to stimuli, differentiation or maturation and mimic human tissue micro-environment, pathological conditions and biological mechanisms much more closely $[1,2]$. 3D culture systems are used in an extensive area of cell-based studies [3], including cell adhesion/migration, tumour biology [4-6], stem cell research [7], regenerative medicine, tissue engineering and preclinical testing in drug discovery [8-11].

There are several approaches for culturing cells in 3D including scaffolds and scaffoldfree techniques. Scaffold-free cultures are advantegous in providing self-assembly of cells and true physiological interactions between different types of cells without any secondary interfering material [12-14]. One of the scaffold-free methods is the micromolded technique utilizing nonadhesive hydrogels, cells of either one type or of more than one type spontaneously aggregate to form 3D microtissue spheroids [12-19] providing physiologically relevant conditions and a suitable platform for testing of drugs at early stage development [16] and high throughput screening processes [9]. In this context, multi-layers of cells within the microtissue spheroid forms natural barriers to drugs as intercellular tight junctions bind cells together and block or slow down the diffusion of drugs as in human tissues [19].

The aim of the present study was to create scaffold-free microtissue spheroids using 3D Petri Dish ${ }^{\circledR}$ technique [20-22] that mimic the cellular microenvironment of SH-SY5Y and SK-N-AS neuronal cell lines that are commonly used as in vitro models for neurodegenerative diseases and neuroblastoma research [23, 24]. We have investigated the microtissue spheroids forming potential/capacity of these cell lines as in vitro 3D models, and the effective size of them considering diffusional transport limitations for oxygen and other essential nutrients. Such engineered models will help identification of molecular mechanisms under strictly controlled conditions and represent a significant step towards uncovering causes of neurodegenerative diseases, as well as facilitate fast and reliable highthroughput pre-clinical screening of novel drugs.

\section{MATERIALS AND METHOD}

\subsection{Cell Culture}

SH-SY5Y (cat. CRL-2266 ${ }^{\mathrm{TM}}$, ATCC $^{\circledR}$ ) and SK-N-AS (cat. CRL-2137 ${ }^{\mathrm{TM}}$, ATCC $^{\circledR}$, passage 5-11, Figure 1) neuroblastoma cells were obtained from Ege University, Bioengineering Department, Animal Cell Culture and Tissue Engineering Labratory Collection. Cells were cultured in Dulbecco's modified Eagle's medium (DMEM, D5796, Sigma-Aldrich, Life Science, St. Louis, Missouri, ABD) containing high glucose (4500 $\mathrm{mg} / \mathrm{L}), 1 \%(\mathrm{v} / \mathrm{v}) \mathrm{L}$-glutamine, $\mathrm{NaHCO}_{3}$, and pyridoxine $\mathrm{HCl}$. This medium was supplemented with $20 \%$ (v/v) heat-inactivated fetal bovine serum (FBS, S0113, Biochrom, Germany) and $0,1 \%$ (v/v) gentamicin (15750-060, Thermo-Fisher Scientific, Waltham, Massachusetts, ABD). Cells were cultivated in $\mathrm{T} 75$ flasks at $37{ }^{\circ} \mathrm{C}$ with $5 \% \mathrm{CO}_{2}$ at saturated humidity $(95 \%)$. 


\subsection{Manufacturing of SH-SY5Y and SK-N-AS Microtissue Spheroids}

Microtissue spheroids of SH-SY5Y and SK-N-AS were manufactured, using 3D petri dish technique [25]. $330 \mu \mathrm{L}$ molten $2 \%(\mathrm{w} / \mathrm{v})$ agarose containing $0,9 \%(\mathrm{w} / \mathrm{v}) \mathrm{NaCl}$ was poured into $800 \mu \mathrm{m}$ diameter micro-molds (MicroTissues, Inc., Sharon, MA, USA). After non-adhesive agarose was gelled at room temperature, the micro-molds were carefully flexed to remove the 3D Petri dishes and conditioned with the cell culture medium for 30 minutes. $75 \mu \mathrm{L}$ cell suspensions of SH-SY5Y and SK-N-AS at $10^{5}, 5 \times 10^{5}$ and $10^{6}$ cells/75 $\mu \mathrm{L}$ concentrations were added to each 3D petri dish and grown in agarose microwells, and incubated at $37^{\circ} \mathrm{C}$ in $5 \% \mathrm{CO}_{2}$ atmosphere at saturated humidity (95\%) for 5 days. Medium was changed every second day and microtissue forming capacity of SH-SY5Y and SK-N-AS cell lines was observed visually by inverted light microscopy (Axio Vert.A1, Zeiss, Germany) at 4X.

\subsection{Size Analysis of Microtissue Spheroids}

To determine suitable agarose mold size and incubation time for most stable microtissue formation, diameters of SH-SY5Y and SK-N-AS microtissue spheroids were measured via ImageJ version 1.46r (NIH, Bethesda, Maryland, USA) and average diameter of spheroids was expressed and graphed as mean \pm standard deviation (SD) by two-way analysis of variance (ANOVA) in GraphPad Prism version 6 for Windows (GraphPad Software, San Diego California USA). $p<.05$ was considered statistically significant.

\section{RESULTS AND DISCUSSION}

Both SH-SY5Y and SK-N-AS (Figure 1) neuroblastoma cell lines grew as monolayers homogeneously and they showed neuronal morphology with extended neurites, as expected $[26,27]$.
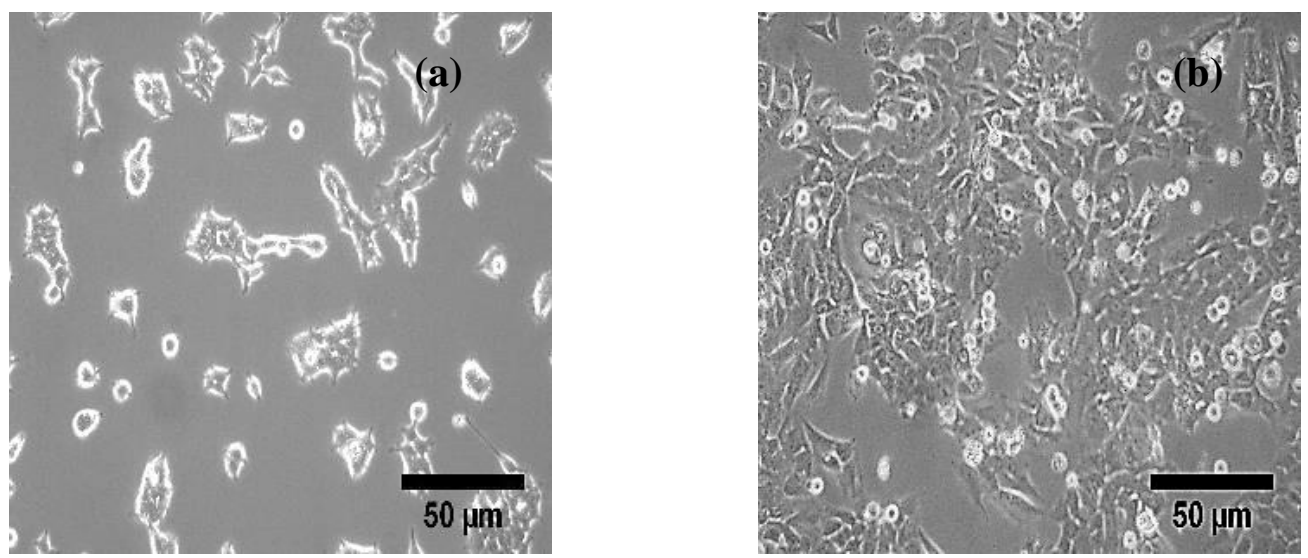

Figure 1. (a) SH-SY5Y and (b) SK-N-AS cell lines at 20X

Both SH-SY5Y and SK-N-AS cell lines started to self-assembly into microtissue spheroids within the microwells of an agarose mold on day 1 (Figures 2-3). Kumar et al. mentioned different neuroblastoma cell lines, including SK-N-AS had potential to form spherical shape naturally [28]. In this study with using the 3D Petri Dish ${ }^{\circledR}$ technique, we saw that both cell lines at different concentrations were able to form microtissue spheroids. If the distance between cells are close, cell-cell interactions will dominate due to adhesive and cohesive forces, and cells will form microtissue spheroids, and they will be able to grow in an 
in vivo-like microenvironment [17, 29]. SH-SY5Y microtissue spheroids had more regular morphology and the spheroids at each concentration had similar shape on $1^{\text {st }}$ and $2^{\text {nd }}$ days. However, after $3^{\text {rd }}$ day, we observed that the microtissues started to fall apart. On the other hand, SK-N-AS microtissue spheroids were unstable and they tended to fall apart from $1^{\text {st }}$ day. This could be SH-SY5Y cell line had better cell-cell interactions compared to SK-N-AS.

The average diameter of SH-SY5Y spheroids was measured as $398.64 \mu \mathrm{m}$ on the $1^{\text {st }}$ day, $458.98 \mu \mathrm{m}$ on the $2^{\text {nd }}$ day, and $430.54 \mu \mathrm{m}$ on the $5^{\text {th }}$ day; and a significant increase between the $1^{\text {st }}$ and the $2^{\text {nd }}$ days $(p<0.05)$ was determined. However, after the $2^{\text {nd }}$ day, the average diameter of the spheroids decreased. This decrease might be because cell concentration $\left(10^{5}\right.$ cells $/ 75 \mu \mathrm{L}$ ) wasn't enough for cells to interact with each other, and the spheroids were dissambled. The average diameter of SH-SY5Y spheroids at $5 \times 10^{5}$ cells $/ 75 \mu \mathrm{L}$ was measured as $660 \mu \mathrm{m}$ on the $1^{\text {st }}$ day, $569.90 \mu \mathrm{m}$ on the $2^{\text {nd }}$ day, and $584.16 \mu \mathrm{m}$ on the $5^{\text {th }}$ day.

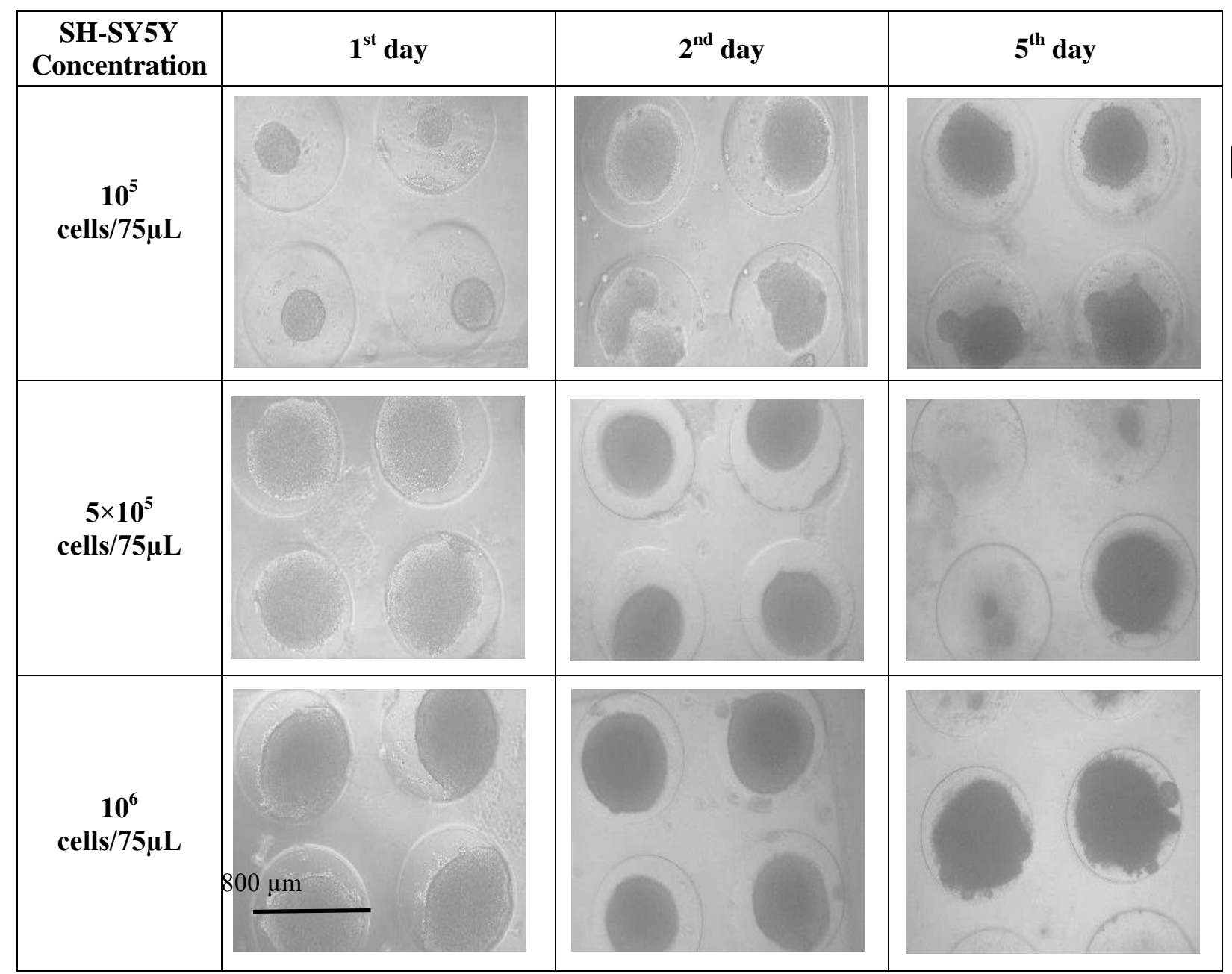

Figure 2. Self assembly of SH-SY5Y microtissue spheroids within the agarose 3D Petri dishes $\left(10^{5}, 5 \times 10^{5}\right.$ and $10^{6}$ cells $\left./ 75 \mu \mathrm{L}\right)$ on the 1 st, 2 nd and 5 th days $(4 \mathrm{X})$

SH-SY5Y spheroid sizes were bigger at this concentration than at $10^{5}$ cells $/ 75 \mu \mathrm{L}$. We observed a significant decrease of the average diameter between the $1^{\text {st }}$ and the $2^{\text {nd }}$ days $(p$ $<0.0001)$, and the size did not change much until the $5^{\text {th }}$ day $(p<0.001)$. The decrease in size is an indicator of high cell to cell interactions, and formation of tight connections between the 
cells. The incubation time might be increased, but we observed that the spheroids began to fall apart on the $5^{\text {th }}$ day.

At $10^{6}$ cells/75 $\mu \mathrm{L}$ concentration, SH-SY5Y microtissue spheroids' diameter was measured as $710.00 \mu \mathrm{m}$ on the $1^{\text {st }}$ day, $576.65 \mu \mathrm{m}$ on the $2^{\text {nd }}$ day, and $703.45 \mu \mathrm{m}$ on the $5^{\text {th }}$ day. A significant contraction on the $2^{\text {nd }}$ day was evident similar to the previous concentration, followed by a significant increase on the $5^{\text {th }}$ day $(p<0.0001)$ (Figure 4). This behavior shows the development of tight connections between the cells on the first two days. Ozturk et al. showed in their study with SaOs-2 osteoblastic cell spheroids, a similar decrease of size of spheroids [29]. The size increase afterwards might be due to a decrease in the cell to cell interactions and/or a fast proliferation rate, which needs to be tested for further evaluations. However, the evidence of spheroids' starting to fill the mold and lose their regular shape on the 5th day, seen on Figure 2, suggests that the cell number is substantially high, causing the cells to abandon their self assembly characteristics.

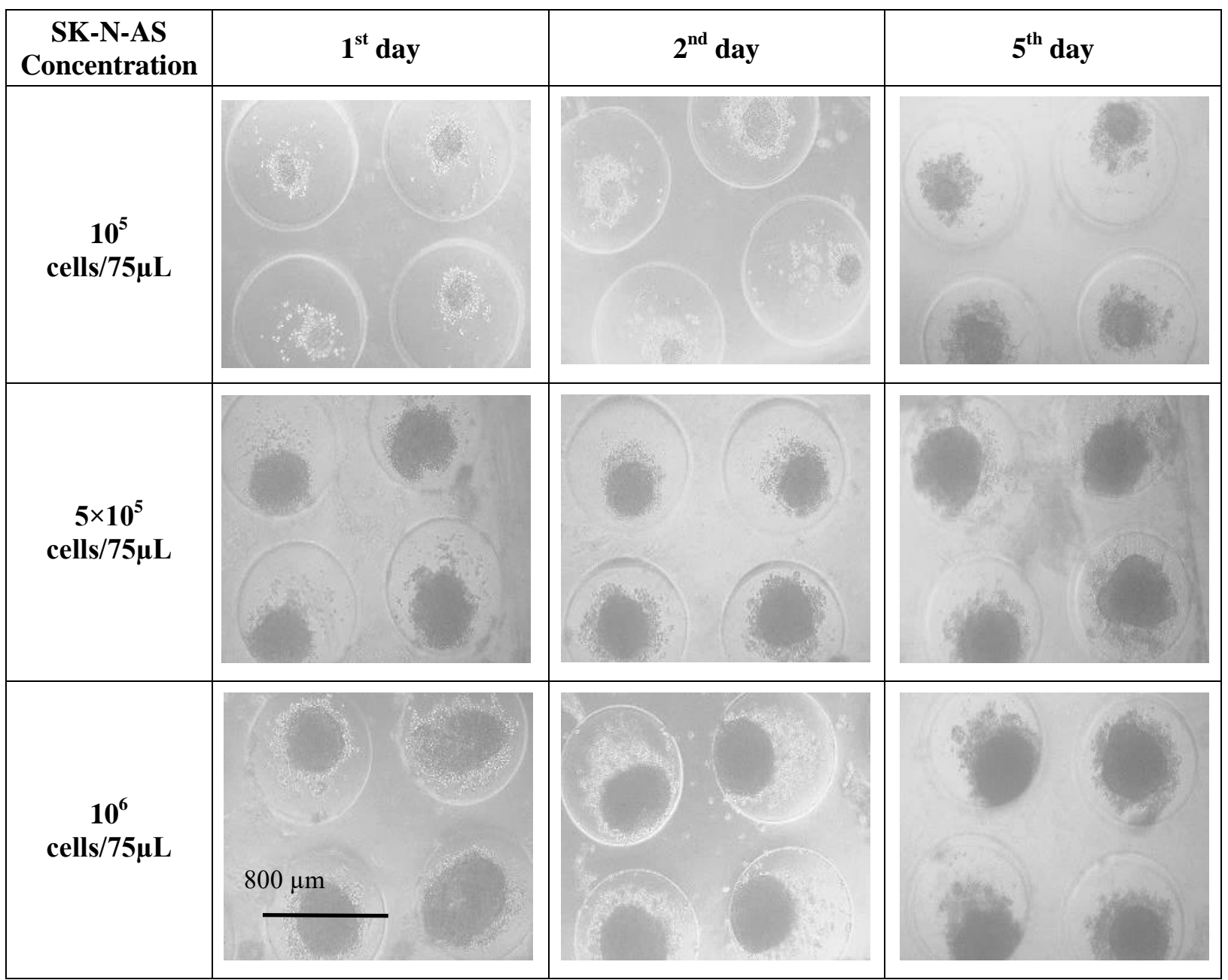

Figure 3. Self assembly of SK-N-AS microtissue spheroids within the agarose 3D Petri dishes $\left(10^{5}, 5 \times 10^{5}\right.$ and $10^{6}$ cells/75 $\left.\mu \mathrm{L}\right)$ on the 1 st, 2 nd and 5 th days $(4 \mathrm{X})$ 
SH-SY5Y

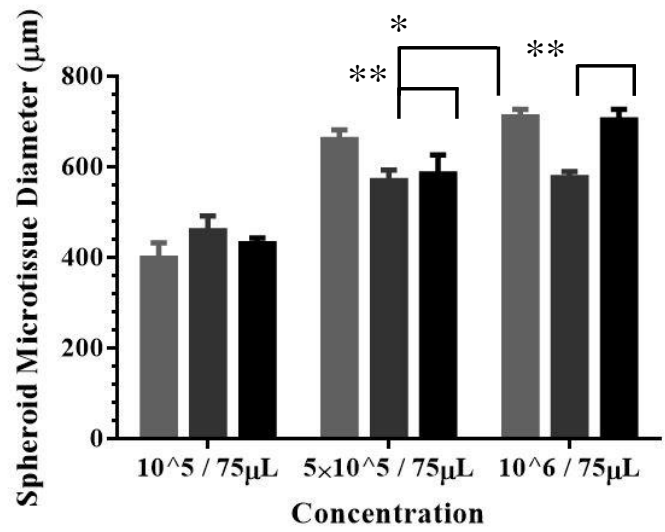

SK-N-AS

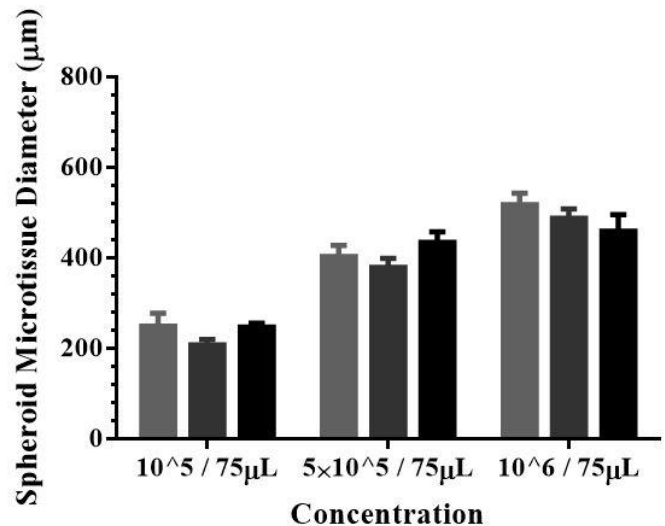

Figure 4. The change of average diameter of (a) SH-SY5Y and (b) SK-N-AS microtissue spheroids at $10^{5}$, $5 \times 10^{5}$ ve $10^{6}$ cells $/ 75 \mu \mathrm{L}$ concentration for 5 days $(* * \mathrm{p}<0.0001, * \mathrm{p}<0.001)$

In accordance with the size analysis of SK-N-AS microtissue spheroids, at $10^{5}$ cells $/ 75 \mu \mathrm{L}$ concentration, the average diameters were measured as $248.00 \mu \mathrm{m}, 206.70 \mu \mathrm{m}$ and 246.30 $\mu \mathrm{m}$; at $5 \times 10^{5}$ cells $/ 75 \mu \mathrm{L}$ concentration as $402.15 \mu \mathrm{m}, 378.5 \mu \mathrm{m}$ and $433.75 \mu \mathrm{m}$; and at $10^{6}$ cells $/ 75 \mu \mathrm{L}$ concentration as $518.15 \mu \mathrm{m}, 487.26 \mu \mathrm{m}$ and $458.41 \mu \mathrm{m}$ on the $1^{\text {st }}, 2^{\text {nd }}$ and $5^{\text {th }}$ days, respectively. The average diameter values of SK-N-AS microtissue spheroids did not show any significant change on any time point at tested concentrations. Additionally, all the microscopy images at each cell concentration indicated that SK-N-AS microtissue spheroids were unstable from the $1^{\text {st }}$ day. The interactions of SK-N-AS cells weren't enough to form stable microtissue spheroids for 5 days. If the incubation time is extended, increased interactions between the cells and size of the spheroids might be seen.

\section{CONCLUSION}

All the results indicate that microtissue forming capacity of SH-SY5Ycell line was more appropriate than SK-N-AS cell line and SH-SY5Y spheroids can be used as an alternative, fast, cheap and easy scaffold-free in vitro 3D model for neurodegenerative diseases and neuroblastoma research.

\section{REFERENCES}

[1] LaPlaca MC, Shoemaker JT, Cullen DK. Three-dimensional Neuronal Cultures, Methods in Bioengineering: 3d Tissue Engineering, Artech House, 2010, pp.187-204.

[2] Asthana A, Kisaalita WS. Biophysical Microenvironment and 3d Culture Physiological Relevance, Drug Discov Today, Vol. 18, No. 11-12, 2013, pp.533-540.

[3] Justice BA, Badr NA, Felder RA, 3d Cell Culture Opens New Dimensions in Cell-Based Assays, Drug Discov Today, Vol. 14, No. 1-2, 2009, pp.102-107.

[4] Hirschhaeuser F, Menne H, Dittfeld C, West J, Mueller-Klieser W, Kunz-Schughart LA. Multicellular Tumor Spheroids: An Underestimated Tool is Catching Up Again, $J$ Biotechnol, Vol. 148, No. 1, 2010, pp.3-15. 
[5] Chitcholtan K, Asselin E, Parent S, Sykes HP, Evans JJ. Differences in Growth Properties of Endometrial Cancer in Three Dimensional (3d) Cculture and 2d Cell Monolayer, Exp Cell Res, Vol. 319, No. 1, 2013, pp.75-87.

[6] Hakanson M, Cukierman E, Charnley M. Miniaturized Pre-Clinical Cancer Models As Research and Diagnostic Tools, Adv Drug Deliv Rev, Vol. 69-70, 2014, pp.52-66.

[7] Penick KJ, Solchaga LA, Welter JF. High-Throughput Aggregate Culture System to Assess the Chondrogenic Potential of Mesenchymal Stem Cells, Biotechniques, Vol. 39, No. 5, 2005, pp.687-691.

[8] Bhadriraju K, Chen CS. Engineering Cellular Microenvironments to Improve Cell-Based Drug Testing, Drug Discov Today, Vol. 7, No. 11, 2002, pp.612-620.

[9] Drewitz M, Helbling M, Fried N, Bieri M, Moritz W, Lichtenberg J, Kelm JM. Towards Automated Production and Drug Sensitivity Testing Using Scaffold-Free Spherical Tumor Microtissues, Biotechnol J, Vol. 6, No. 12, 2011, pp.1488-1496.

[10] Breslin S, O'Driscoll L. Three-Dimensional Cell Culture: The Missing Link in Drug Discovery, Drug Discov Today, Vol. 18, No. 5-6, 2013, pp.240-249.

[11] Berg EL, Kunkel EJ, Hytopoulos E. Biological Complexity and Drug Discovery: A Practical Systems Biology Approach, Syst Biol (Stevenage), Vol. 152, No. 4, 2005, pp.201-206.

[12] Kelm JM, Fussenegger M. Microscale Tissue Engineering Using Gravity-Enforced Cell Assembly, Trends Biotechnol, Vol. 22, No. 4, 2004, pp.195-202.

[13] Kelm JM, Djonov V, Ittner LM, Fluri D, Born W, Hoerstrup SP, Fussenegger M. Design of Custom-Shaped Vascularized Tissues Using Microtissue Spheroids as Minimal Building Units, Tissue Engineering, Vol. 12, No. 8, 2006, pp.2151-2160.

[14] Haycock JW. 3d Cell Culture: A Review of Current Approaches and Techniques, Methods Mol Biol, Vol. 695, 2011, pp.1-15.

[15] Achilli TM, Meyer J, Morgan JR. Advances in The Formation, Use and Understanding of Multi-Cellular Spheroids, Expert Opin Biol Ther, Vol. 12, No. 10, 2012, 1347-1360.

[16] Kunz-Schughart LA, Freyer JP, Hofstaedter F, Ebner R, The Use of 3-d Cultures for High-Throughput Screening: The Multicellular Spheroid Model, J Biomol Screen, Vol. 9, No. 4, 2004, pp.273-285.

[17] Napolitano AP, Dean DM, Man AJ, Youssef J, Ho DN, Rago AP, Lech MP, Morgan JR. Scaffold-Free Three-Dimensional Cell Culture Utilizing Micromolded Nonadhesive Hydrogels, Biotechniques, Vol. 43, No. 4, 2007, pp.494, 496-500.

[18] Ebrahimkhani MR, Young CL, Lauffenburger DA, Griffith LG, Borenstein JT. Approaches to in Vitro Tissue Regeneration with Application for Human Disease Modeling and Drug Development, Drug Discov Today, Vol. 19, No. 6, 2014, pp.754-762.

[19] Choudhury D, Mo X, Iliescu C, Tan LL, Tong WH, Yu H. Exploitation of Physical and Chemical Constraints For Three-Dimensional Microtissue Construction in Microfluidics, Biomicrofluidics, Vol. 5, No. 2, 2011.

[20] Desroches BR, Zhang P, Choi BR, King ME, Maldonado AE, Li W, Rago A, Liu G, Nath N, Hartmann KM, Yang B, Koren G, Morgan JR, Mende U. Functional ScaffoldFree 3-D Cardiac Microtissues: A Novel Model for the Investigation of Heart Cells, Am J Physiol Heart Circ Physiol, Vol. 302, No. 10, 2012, pp.2031-2042.

[21] Dissanayaka W, Zhu L, Hargreaves K, Jin L, Zhang C. Scaffold-Free Prevascularized Microtissue Spheroids for Pulp Regeneration, J Dent Res, Vol. 93, No. 12, 2014, pp.1296-1303.

[22] Microtissues Inc. [http://www.microtissues.com/] Access to Date: 02.02.2016.

[23] Lopes FM, Schroder R, da Frota ML Jr, Zanotto-Filho A, Muller CB, Pires AS, Meurer RT, Colpo GD, Gelain DP, Kapczinski F, Moreira JC, Fernandes Mda C, Klamt F. 
Comparison between Proliferative and Neuron-Like Sh-Sy5y Cells as an in Vitro Model for Parkinson Disease Studies, Brain Res, Vol. 1337, 2010, pp.85-94.

[24] Harvey H, Piskareva O, Creevey L, Alcock LC, Buckley PG, O'Sullivan MJ, Segura MF, Gallego S, Stallings RL, Bray IM. Modulation of Chemotherapeutic Drug Resistance in Neuroblastoma Sk-N-As Cells by the Neural Apoptosis Inhibitory Protein and Mir-520f, Int J Cancer, Vol. 136, No. 7, 2015, pp.1579-1588.

[25] Microtissues Inc., Signs exclusive license with Brown University, 2015, [http://www.microtissues.com/mt-pr-microtissues-signs-license-with-brownuniversity.htm] Access to Date: 02.02.2016.

[26] Sh-sy5y (atcc ${ }^{\circledR} \quad$ crl-2266 $\left.{ }^{\mathrm{TM}}\right), \quad$ [http://www.lgcstandards-atcc.org/products/all/CRL266.aspx?geo_country=tr\#characteristics] Access to Date: 07.10.2015.

[27] Sk-n-as (atcc ${ }^{\circledR} \quad$ crl-2137TM), [http://www.lgcstandards-atcc.org/products/all/CRL2137.aspx?geo_country=tr] Access to Date: 04.10.2015.

[28] Kumar HR, Zhong X, Hoelz DJ, Rescorla FJ, Hickey RJ, Malkas LH, Sandoval JA, Three-Dimensional Neuroblastoma Cell Culture: Proteomic Analysis between Monolayer and Multicellular Tumor Spheroids, Pediatr Surg Int, Vol. 24, No. 11, 2008, pp.12291234.

[29] Öztürk S. The Effects of Cancer Stem Cells on Forming and Organiation of Microtissue, Master Thesis, İzmir: Ege University, Graduate School of Natural and Applied Science, Biomedical Technologies Department, 2014.

\title{
CV/ÖZGEÇMiș
}

\begin{abstract}
Aslı Aybike Doğan; Bioengineer, MSc. Student
She has received her BSc degree in Bioengineering in 2015 and currently started doing her master studies (expected date 2017) at Animal Cell Culture and Tissue Engineering Laboratories at the Department of Bioengineering at Ege University in Izmir, Turkey. She was a student investigator of two undergraduate projects funded by TUBITAK. Her undergraduate studies have focused on determination of silk fibroin/hydroxyapatite (SF/HAp) coated poly-ether-ether-ketone (PEEK) spinal implants' biocompatibility and in vitro 3D Parkinson's disease model for preclinical testing of cycloastragenol. She is also interested in neural tissue engineering, artificial brain ECM, in vitro 3D models for diseases associated with brain and therapeutic screening and cell therapy for neurodegenerative/neuropsychiatric disorders.
\end{abstract}

Lisans derecesini 2015 yllında E.Ü. Biyomühendislik Bölümü’nden almış olup, Yüksek Lisans eğitimine yine aynı bölümde devam etmektedir. Lisans eğitimi sırasında, TÜBİTAK tarafindan desteklenen, 2209-A Lisans Projesi “Ipek Fibroin (SF) - Hidroksiapatit (HAp) Kaplanan Polieterketonketon (PEKK) - Hidroksiapatit (HAp) Kompozit Kemik Implantının Mekanik Özelliklerinin ve Biyouyumluluk Karakterinin Belirlenmesi" ve 2209-B Sanayi Odakl Lisans Bitirme Tezi "Dikkat Eksikliği ve Hiperaktivite Bozukluğu (DEHB) ile Parkinson Hastalığı'nın (PH) İki Boyutlu (2B) ve Üç Boyutlu (3B) in vitro Modellerinde Sikloastragenol'ün (SA) Nöroprotektif ve Nörorejeneratif Etkisinin Araştırllmasl” adl projelerin yürütücülüğ̈̈nü üstlenmiştir. Sinir doku mühendisliği, yapay beyin ekstraselüler matrisi, in vitro $3 B$ nörodejeneratif/nöropsikiyatrik hastalık modelleri ve hücre terapisi konuları ilgi alanları arasındadır.

\section{Şeyma Taşdemir; Bioengineer, MSc., PhD. Candidate}

She graduated as a bioengineer from the Ege University (2010), and received a M.Sc in Bioengineering (Ege University, 2013). She is a PhD candidate and research assistant at Ege University, Bioengineering Department. Her M.S theses is on "Investigation of attachment and proliferation properties of rat bone marrow and adipose tissue derived mesenchymal stem cells on PCL nanofibrous surfaces" and her ongoing PhD theses is on "Investigation of the neuroregenerative effects of iron oxide $\left(\mathrm{Fe}_{3} \mathrm{O}_{4}\right)$ nanoparticle and graphene reinforced tissue engineering products on in vitro and in vivo Parkinson's disease models". She has qualified for MSc and PhD scholarship from The Scientific and Technological Research Council of Turkey. Her research interests include animal cell culture, neural tissue engineering, production of scaffolds, electrospinning, stem cells, interactions of cells and biomaterials, biocompatibility tests, in vitro neurodegenerative disease models, 3D micro tissue models. 
Lisans derecesini (2010) ve Yüksek Lisans derecesini (2012), Ege Üniversitesi Biyomühendislik Bölümü'nden almış olup, Doktora eğitimine, yine ayn bölümde, Ar. Gör. unvanıyla devam etmektedir. "Slçan kemik iliğinden ve yă̆ dokusundan elde edilen mezenkimal kök hücrelerin PCL nanofibröz yüzeyler üzerinde tutunma ve çoğalma özelliklerinin incelenmesi" konulu yüksek lisans tezini tamamlamış, "Demir Oksit $\left(\mathrm{Fe}_{3} \mathrm{O}_{4}\right)$ nanopartikülü ve grafen katkılı doku mühendisliği ürünlerinin in vitro ve in vivo Parkinson hastaliğ modelleri üzerindeki etkisi" adl doktora tezini sürdürmektedir. TÜBITTAK tarafindan, yüksek lisans ve doktora bursu almaya hak kazanmıştır. Hayvan hücre kültürü, sinir doku mühendisliği, iskele üretimi, elektroeğirme, kök hücreler, hücre-biyomalzeme etkileşimleri, biyouyumluluk testleri, in vitro nörodejeneratif hastalık modelleri, üç boyutlu (3B) mikro doku modelleri vb. ilgilendiği alanlar arasındadır.

\section{Aylin Şendemir-Ürkmez; Assist. Prof. Dr.}

She has received her B.S. degree at Mechanical Engineering (1994), M.Sc. degree at Biomedical Engineering (1997) from Bogazici University, Turkey, and PhD. degree at Materials Science and Engineering (2006) from University of Illinois at Urbana-Champaign, USA. She has been working as an assistant professor at Ege University Faculty of Engineering, Bioengineering Department since January 2009 and currently the principal investigator at Ege Research Group of Animal Cell Culture and Tissue Engineering (EgeREACT). Her research interests include interactions of animal cells and biomaterials, tissue engineering, mechano-transduction, stem cells, cancer stem cells and biocompatibility testing. She is also interested in design and production of novel in vitro disease models in order to minimize animal testing. She has co-authored more than 20 scientific papers, 2 patents and 3 book chapters. Assist. Prof. Dr. Aylin Şendemir Ürkmez is a member of the Editorial Board of Challenges in Regenerative Medicine.

Lisans derecesini Bŏgaziçi Üniversitesi Makine Mühendisliği (1994), Yüksek Lisans derecesini ise, Boğaziçi Üniversitesi, Biyomedikal Mühendisliği (1997) bölümlerinden almış olup, doktorasını Illinois at UrbanaChampaign Üniversitesi, Malzeme Bilimi ve Mühendisliği (2006) bölümünde tamamlamıştır. 2009 yılının Ocak ayından itibaren, E.Ü., Mühendislik Fakültesi, Biyomühendislik Bölümü'nde Yrd. Doç. Dr. unvanıyla çalışmakta olup, Hayvan Hücre Kültürü ve Doku Mühendisliği Araştırma Grubu (EgeREACT)'ın yürütücülügünü üstlenmektedir. Ilgi alanları arasında, hayvan hücreleri ile biyomalzemelerin etkileşimleri, doku mühendisliği, mekano-transdüksiyon, kök hücreler, kanser kök hücreleri ve biyouyumluluk testleri yer almaktadır. Ayrıca, hayvan denemelerinin minimize edilmesi amaclyla, in vitro hastalı modellerinin dizayn ve üretimiyle ilgilenmektedir. 20'den fazla bilimsel makale, 2 patent ve 3 kitap bölümünün eş yazarlı̆̆ına sahip olmakla birlikte, Yenileyici Tip'taki Zorluklar (Challenges in Regenerative Medicine) adlı derginin editörlüğünü yapmaktadir. 